\title{
Pengaruh Serapan Sistem Pendingin pada Shrinkage untuk Blister dari PVC
}

\author{
Dikky Antonius ${ }^{1)^{\star}}$, Budiarto $^{1)}$, Benedigtus Tito ${ }^{2)}$ \\ ${ }^{1,2,3)}$ Program Studi Teknik Mesin Universitas Kristen Indonesia \\ Jalan Maydjen Sutoyo No.2, Jakarta Timur 13650 \\ Email: dicky.antonius@uki.ac.id; budiarto@uki.ac.id ; benedictusprarismatito@gmail.com
}

doi: https://doi.org/10.24843/METTEK.2020.v06.i01.p04

\begin{abstract}
Abstrak
Proses thermoforming dilakukan dengan memanaskan material lembaran plastik kemudian diberi tekanan atau vakum ke rongga cetakan untuk mendapatkan bentuk yang diinginkan. Pada penelitian ini, proses thermoforming diaplikasikan untuk membuat Blister. Dimana Blister adalah tempat memasukan obat berbentuk pila tau kapsul. Temperatur air pendingin (forming temperature) diatur dari mulai $19^{\circ} \mathrm{C}, 21^{\circ} \mathrm{C}$ dan $25^{\circ} \mathrm{C}$, sementara temperatur pemanasan (heating temperature) disusun dari mulai $110^{\circ} \mathrm{C}, 120^{\circ} \mathrm{C}$ dan $130^{\circ} \mathrm{C}$ untuk masing-masing temperatur air pendinginan. Kualitas Blister diukur dengan metode visual, serta menggunakan jangka sorong digital untuk melihat shrinkage (cacat penyusutan) yang mungkin terjadi. Kebocoran blister juga dicek dengan menggunakan pompa vakum. Hasil akhir menunjukkan bahwa seiring temperatur air pendingin dinaikkan, maka energi yang dilepas oleh mesin sebagai panas semakin turun diakibatkan perbedaan antara temperatur pemanasan dan pendinginan yang semakin sedikit. Pengujian toleransi ukuran menggunakan jangka sorong memperlihatkan bahwa penyusutan terjauh dialami oleh sampel dengan temperatur pemanasan $110^{\circ} \mathrm{C}$, pengujian visual juga menyatakan hasil dari sampel pada temperatur pemanasan $110 \mathrm{oC}$ tidak terbentuk semuanya. Sampel dengan temperatur pemanasan $120^{\circ} \mathrm{C}$ dan $130^{\circ} \mathrm{C}$ mempunyai kualitas yang jauh lebih baik dalam hal toleransi dibandingkan temperatur pemanasan $110^{\circ} \mathrm{C}$. Toleransi terbaik ditunjukkan oleh sampel dengan temperatur pemanasan $130^{\circ} \mathrm{C}$ dan pendinginan $25^{\circ} \mathrm{C}$, namun sayangnya, dari pengujian vakum, parameter ini menunjukkan indikasi kebocoran.
\end{abstract}

Kata kunci: Thermoforming, Blister forming

\begin{abstract}
Thermoforming is one of the forming process which heating the material-usually plastic - then pressurized to form the shape. In this research thermoforming processes applied to make a Blister. Blister is one of the medicine container - usually capsule. The forming temperature is set in $19^{\circ} \mathrm{C}, 21^{\circ} \mathrm{C}$, and $25^{\circ} \mathrm{C}$, meanwhile heating temperature is set in $110^{\circ} \mathrm{C}, 120^{\circ} \mathrm{C}$ and $130^{\circ} \mathrm{C}$. The quality check by visual and using digital caliper to check the shrinkage. Meanwhile, the vacuum pump is used to check the leak of Blister. The result shows that the energy released by the machine is smaller when the forming temperature is increased, caused by the differentiation of the heating temperature and the forming temperature. The highest shrinkage shown in the sample heated at $110^{\circ} \mathrm{C}$ and formed at temperature $19^{\circ} \mathrm{C}$. However, by visual check, the sample heated at $110^{\circ} \mathrm{C}$ is broken regardless the forming temperature made. Better quality shown in the sample heated at $120^{\circ} \mathrm{C}$ and $130^{\circ} \mathrm{C}$. The lowest shrinkage shown by the sample heated at $130^{\circ} \mathrm{C}$ and formed at $25^{\circ} \mathrm{C}$, however the vacuum test indicated there are leak in the Blister.
\end{abstract}

Keywords: Thermoforming, Blister forming

Penulis korespondensi

Email: dicky.antonius@uki.ac.id 


\section{PENDAHULUAN}

Proses termoforming adalah proses pembentukan material yang dilakukan dengan memanaskan material tersebut, dan kemudian memberikan tekanan vakum pada bagian cetakan, sehingga material yang sudah panas tersebut akan tertarik mengikuti bentuk dari cetakan. Biasanya proses ini dilakukan pada plastik atau karet. Produk umum dari proses ini biasanya berupa printer, pipa, atau blister yang merupakan pembungkus dari kapsul[1], [2].

Sama halnya dengan injection molding, proses pembentukan ini membutuhkan pendinginan, sehingga material kembali pada temperatur normal dengan bentuk yang sudah diubah sesuai dari cetakannya. Oleh karena itu, jenis cacat dari proses pembentukan ini juga hampir sama dengan jenis cacat pada proses pembentukan dengan metode molding lainnya. Shrinkage atau biasa dikenal dengan penyusutan ukuran merupakan hal yang sering ditemukan dalam proses thermoforming, diikuti dengan kebocoran, dan cacat lainnya.

Beberapa publikasi tentang sistem pembentukan menggunakan cetakan seperti injection molding, blow molding, dan lainnya, telah menjelaskan bahwa proses pendinginan, baik itu media maupun temperatur pendinginannya akan sangat mempengaruhi cacat dari produk yang mungkin terjadi, baik itu untuk produk dengan logam maupun produk plastik.[3]. Hal yang sama dimungkinkan terjadi pada proses termoforming ini. Oleh karena itu menarik untuk melihat penyelidikan dan penelitian tentang sistem pendingin cetakan dan pengaruhnya pada hasil cetakan

Ramadhan meneliti tentang perbandingan cacat produk plastik yang terjadi pada proses injection molding dengan Cooling Tower dan dengan menggunakan udara[4]. Penelitian menunjukkan bahwa cacat produk berkurang ketika menggunakan Cooling Tower dibandingkan dengan udara. Dengan kata lain penelitian ini sedang mengatakan bahwa jumlah kalor yang terserap pada proses pendinginan akan menunjukkan cacat yang jauh lebih sedikit. Sayangnya penelitian ini tidak memperlihatkan dengan jelas kualitas dari hasil cetakan.

Lebih jauh lagi Estu meneliti tentang pengaruh sistem pendinginan pada produknya berupa Ts Slug berbahan PVC dengan proses injection molding [5]. Penelitian jelas menunjukkan bahwa kecepatan pendinginan yang berbeda akan menghasilkan penyusutan yang berbeda pula. Dalam penelitian ini dibandingkan 3 jenis media pendingin juga, yaitu MTC, Cooling Tower dan chiller. Colling tower mempunyai kecepatan pendinginan yang lebih cepat dari MTC, namun lebih lambat sedikit dari chiller, walau demikian penyusutan terkecil dialami produk dengan pendinginan cooling tower. Walau demikian, hal ini akan sulit dikarenakan sistem pendinginan yang diperuntukkan bagi proses termoforming mempunyai ruang yang sedikit terbatas ketimbang dengan proses injection molding.

Lebih detil lagi, beberapa peneliti menjelaskan pengaruh tipe saluran pendingin lurus dan conformal terhadap cacat yang terjadi.[6], begitu juga pengaruh diameter saluran pendingin terhadap penyusutan produk [7]-[9]. Namun dari beberapa penjelasan yang disediakan penelitian-penelitian ini tidak dijelaskan secara detail berapa kalor yang terserap pada cetakan dan berapa kalor yang terserap pada air pendingin

Beberapa penelitian menunjukkan cara pandang lain untuk mengatasi cacat produk dengan cara melihat pengaruh temperatur pemanasan terhadap hasil penyusutan [10], [11]. Pemanasan dengan temperatur yang tinggi, jelas akan mengakibatkan material berubah pada struktur tertentu, khususnya plastik. Ditambah lagi, perpindahan panas yang terjadi pun akan semakin besar karena proses pendinginan yang diperlukan akan semakin besar. Namun sayangnya ini tidak bisa dijadikan panduan tentang pendinginan yang lebih baik, dikarenakan temperatur pemanasan akan mempengaruhi struktur material ketimbang penyusutannya.

Penelitian terbaru menjelaskan tentang proses termoforming pada produk yang sama dengan penelitian ini - Blister [12]. Proses ini menunjukkan jelas pengaruh temperatur forming hingga waktu yang dibutuhkan untuk menyusut. Walau demikian, penelitian ini tidak 
difokuskan kepada sistem pendinginannya, dikarenakan penelitian ini hanya membandingkan sistem lama dan baru.

Pengubahan struktur pendingin, media pendingin, tipe pendingin, dan lainnya pada dasarnya mempunyai fokus yang sama, yaitu kecepatan pendingin dan juga besar kalor yang diserap oleh sistem pendingin. Oleh karena itu, penelitian ini bertujuan untuk memperlihatkan secara detail tentang pengaruh besarnya serapan (persentase) kalor yang diserap oleh sistem pendingin dari termoforming dan pengaruhnya terhadap kualitas cetakan, sehingga ke depan peneliti-peneliti lain dapat memperkirakan sistem pendinginan yang cocok dengan melihat besarnya persentase serapan kalor dari sistem pendingin.

\section{METODE}

\subsection{Bahan dan Material}

Dalam penelitian ini bahan yang digunakan adalah material jenis PVC (pholyvinyl Chloride) dengan lebar 149mm dan ketebalan 0,35mm. Gambar 1 menunjukkan jenis material tersebut, dan Tabel 1 menjelaskan tentang spesifikasinya

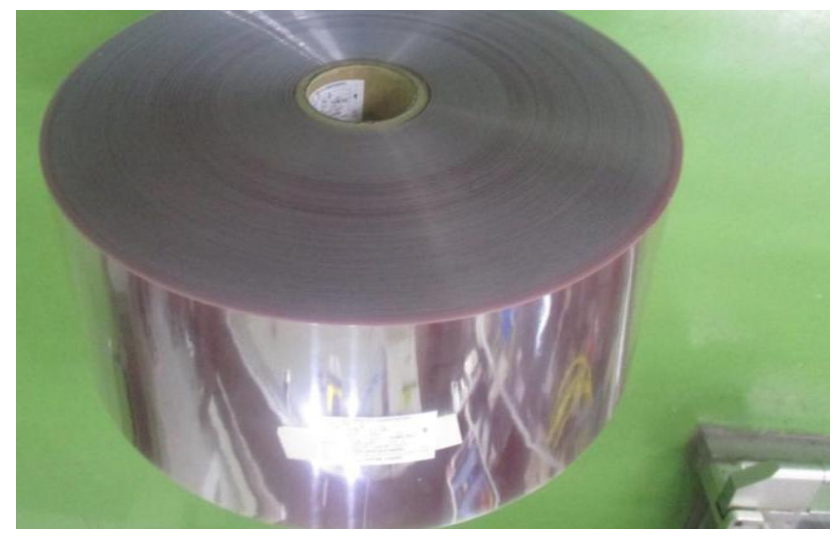

Gambar 1. Spesifikasi material PVC

Tabel 1. Spesifikasi dari Material PVC yang digunakan

\begin{tabular}{ll}
\hline Karakterisasi & Besaran \\
\hline Tebal Bahan & $0.35 \mathrm{~mm}$ \\
Masssa jenis & $1630 \mathrm{~kg} / \mathrm{m}^{3}$ \\
Konduktivitas termal $(\mathrm{K})$ & $0,13 \mathrm{~W} / \mathrm{mK}$ \\
Panas jenis $(\mathrm{Cp})$ & $1,259 \mathrm{~J} / \mathrm{KgK}[13]$ \\
\hline
\end{tabular}

Sementara Mesin yang digunakan adalah mesin Uhlmann UPS B1240, seperti yagn tampak pada gambar 2

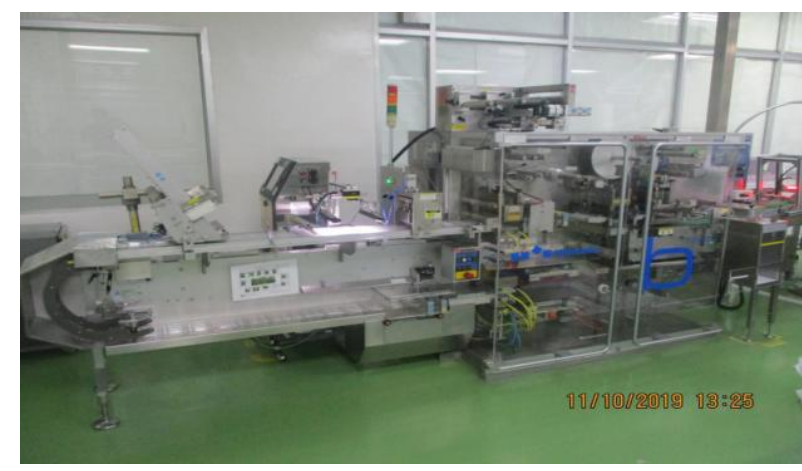

Gambar 2. Mesin Uhlmann PS B1240 
Sebelum masuk ke mesin maka material PVC yang bentuknya masih gulungan besar tersebut, dipotong menjadi dimensi $170 \times 100 \times 0,35 \mathrm{~mm}$. Sementara setelah masuk mesin maka bentuk spesimen diharapkan membentuk sampel seperti pada gambar 3 .

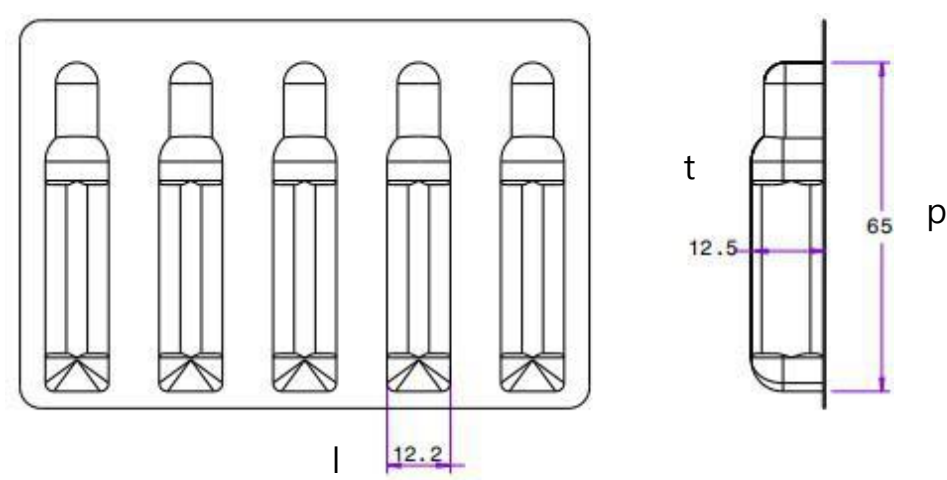

Gambar 3. Dimensi sampel setelah melewati mesin

Dengan $\mathrm{p}$ sebagai panjang, 1 sebagai lebar dan $\mathrm{t}$ sebagai tinggi. Pada mesin, temperatur pemanasan diatur mulai $110^{\circ} \mathrm{C}, 120^{\circ} \mathrm{C}$ dan $130^{\circ} \mathrm{C}$, sementara temperatur air pendingin - yang diharapkan jadi temperatur pembentukan (forming temperature) - diatur pada $19^{\circ} \mathrm{C}, 21^{\circ} \mathrm{C}$ dan $25^{\circ} \mathrm{C}$ dengan Deionize water sebagai air pendingin. Penggunaan deinoize water dimaksudkan agar tidak terjadi kontaminasi jika terjadi kebocoran pada bagian pendinginan. Masing-masing temperatur pendingin dipasangkan untuk tiap 3 temperatur pemanasan. Jadi parameternya akan terlihat seperti tabel dibawah, berikut dengan penamaannya

Tabel 2. Penamaan dan parameter sampel

\begin{tabular}{ccc}
$\begin{array}{c}\text { Spesimen } \\
\text { Uji }\end{array}$ & $\begin{array}{c}\text { Temperatur } \\
\text { forming }\left({ }^{\circ} \mathrm{C}\right)\end{array}$ & $\begin{array}{c}\text { Temperatur } \\
\text { heating }\left({ }^{\circ} \mathrm{C}\right)\end{array}$ \\
\hline A.1 & \multirow{2}{*}{19} & 110 \\
A.2 & & 120 \\
A.3 & & 130 \\
\hline B.1 & & 110 \\
B.2 & 21 & 120 \\
B.3 & & 130 \\
\hline C.1 & & 110 \\
C.2 & 25 & 120 \\
C.3 & & 130 \\
\hline
\end{tabular}

Sedangkan sistem pendingin yang digunakan mempunyai volume sebesar 15 liter dengan spesifikasi tertentu. Berikut adalah tabel spesifikasi dari sistem pendinginnya:

Tabel 3. Spesifikasi Sistem pendingin mesin

\begin{tabular}{ll}
\hline Spek & Besaran \\
\hline Debit Air pendingin $(\mathrm{Qh})$ & $0,00016 \mathrm{~m}^{3} / \mathrm{s}$ \\
Dynamic Viscosity $(\eta)$ & $0,00000152 \mathrm{Kgm} . \mathrm{s}$ \\
Media pendingin & Deionize water \\
Massa Jenis & $1000 \mathrm{~kg} / \mathrm{m}^{3}$ \\
Panjang Saluran pendingin & $3 \mathrm{~m}$ \\
Diameter saluran pendingin & $0,008 \mathrm{~m}$ \\
Tebal Forming unit & $0,05 \mathrm{~m}$ \\
\hline
\end{tabular}




\subsection{Persamaan}

Persamaan yang digunakan dalam hal ini hanyalah kalkulasi untuk memperhitungkan halhal yang akan dimasukkan dalam tabel

Untuk memperhitungkan volume, penulis menggunakan rumus:

$$
V_{\text {plastik }}=p . l . t
$$

Dan untuk mencari masa, maka digunakan rumus:

$$
m_{\text {plastik }}=V_{\text {plastik }} \rho_{\text {pve }}
$$

Dari pencarian massa diatas, maka akan dicari kalor yang dilepas dari mesin kepada cetakan dengan menggunakan rumus:

$$
W=m_{\text {plastik }} C_{p \text { plastik }}\left(T_{2}-T_{1}\right)
$$

Dimana $\mathrm{T}_{1}$ adalah temperatur air pendingin (forming temperature), dan $\mathrm{T}_{2}$ adalah temperatur pemanasan (heating temperature).

Kemudian untuk mencari kalor yang diserap pada air pendingin, sehingga dapat memprediksi kecepatan pendinginan dan persentase kalor yang terhisap, maka persamaan (2) dapat digunakan untuk menghitung massa air pada sistem pendingin, dan kemudian rumus (3) dapat digunakan kembali untuk mencari kalor yang diserap dan kecepatan pendinginan yang terjadi.

\subsection{Pengukuran}

Pengukuran dilakukan secara visual dan dengan jangka sorong digital untuk memperlihatkan penyusutan yang terjadi. Sedang pompa vakum diperuntukkan bagi tes kebocoran pada blister.

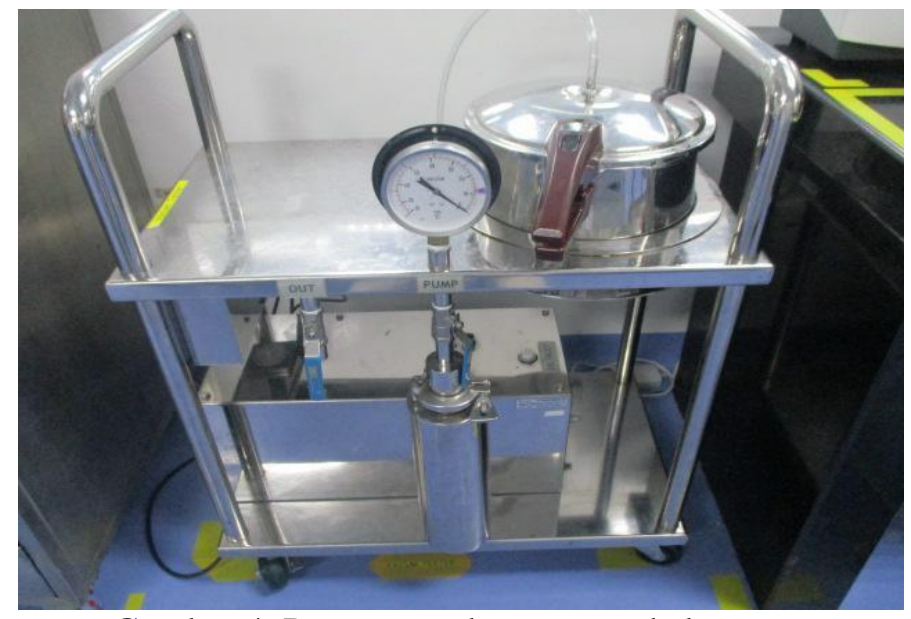

Gambar 4. Pompa untuk mengetes kebocoran

\section{HASIL DAN PEMBAHASAN}

\subsection{Penyerapan Kalor}

Penggunaan rumus (1) menghasilkan volume sebesar $5,95.10^{-6} \mathrm{~m}^{3}$. Volume ini kemudian digunakan untuk menentukan massa dengan menggunakan rumus (2). Hasil ditunjukkan bahwa massa dari tiap lembar spesimen PVC adalah $9,698.10^{-3} \mathrm{~kg}$.

Kemudian dengan menggunakan rumus (3), maka kalor yang diserap dan diberikan mesin kepada cetakan dapat diperlihatkan pada Tabel 4 dan Gambar 5 sesuai dengan parameternya masing-masing. 
Tabel 4. Hasil penyerapan Kalor yang diserap oleh cetakan

\begin{tabular}{|c|c|c|c|c|c|}
\hline $\begin{array}{c}\text { Spesimen } \\
\text { Uji }\end{array}$ & $\begin{array}{l}\text { Temperatur } \\
\text { forming }\left({ }^{\circ} \mathrm{C}\right)\end{array}$ & $\begin{array}{l}\text { Temperatur } \\
\text { heating }\left({ }^{\circ} \mathrm{C}\right)\end{array}$ & $\begin{array}{l}\text { Massa } \\
\text { PVC } \\
(\mathrm{Kg})\end{array}$ & $\begin{array}{r}C p_{\text {plastik }} \\
\left(\mathrm{J} / \mathrm{kg}^{\circ} \mathrm{C}\right)\end{array}$ & $\begin{array}{l}\dot{W}_{\text {plastik }} \\
\text { (Joule) }\end{array}$ \\
\hline A. 1 & \multirow{3}{*}{19} & 110 & & & 1111 \\
\hline A. 2 & & 120 & & & 1233 \\
\hline A. 3 & & 130 & & & 1355 \\
\hline B.1 & \multirow{3}{*}{21} & 110 & \multirow{3}{*}{$\begin{array}{c}9,698 \\
10^{-3}\end{array}$} & \multirow{3}{*}{1259} & 1086 \\
\hline B. 2 & & 120 & & & 1208 \\
\hline B. 3 & & 130 & & & 1330 \\
\hline C.1 & \multirow{3}{*}{25} & 110 & & & 1037 \\
\hline C. 2 & & 120 & & & 1159 \\
\hline C. 3 & & 130 & & & 1282 \\
\hline
\end{tabular}

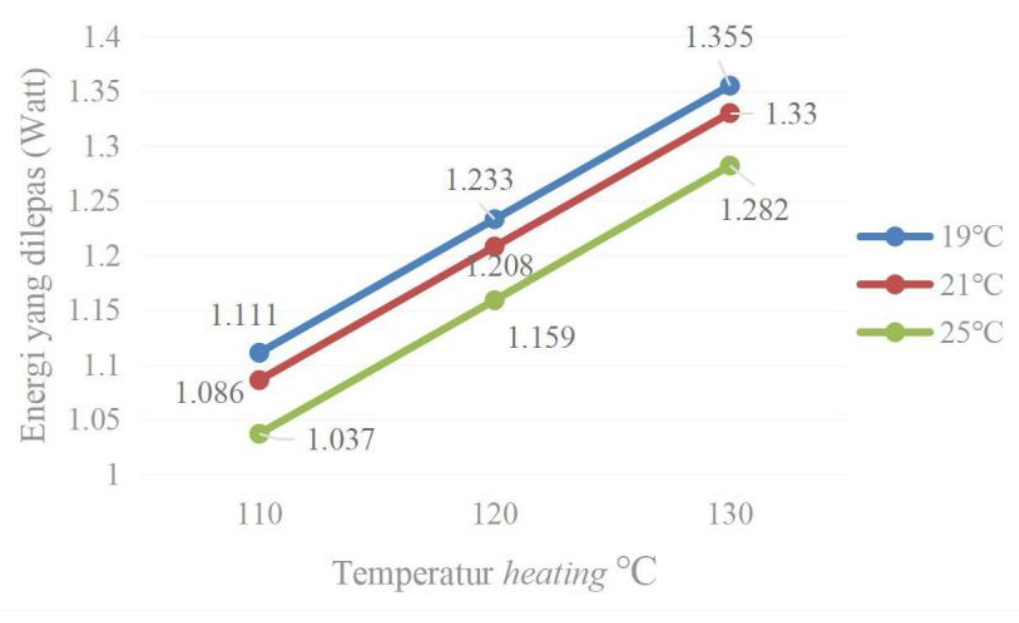

Gambar 5. Kalor yang diserap oleh cetakan

Dari grafik, terlihat jelas bahwa, kalor yang diserap oleh cetakan akan semakin besar seiring dengan penambahan temperatur pemanasannya dan dengan pengurangan temperatur pendinginannya (forming temperature) dimana hal ini sinkron dengan penelitian-penelitian terdahulu[11]. Hal ini dapat dijelaskan dengan rumus (3) dimana $T_{2}$ dinyatakan dengan temperatur pemanasan dan $\mathrm{T}_{1}$ adalah temperatur pendinginannya. Jika temperatur pemanasan dinaikkan, atau temperatur pendinginan diturunkan, maka perbedaan temperatur yang menjadi pengali akan semakin besar dan berkonsekuensi membesarkan kalor yang diserap.

Untuk mencari kalor yang diserap oleh sistem pendingin, maka dicari dahulu temperatur air pendingin aktual setelah cetakan dibuat selamat 30 menit. Dengan melihat Tabel 3, maka kita akan segera mendapatkan volume dari air yang dipasang $1,507.10^{-4} \mathrm{~m}^{3}$. Dengan memakai rumus (2), maka kita akan mendapatkan massa sebesar 0,1507kg. Dengan menggunakan spesifikasi pada Tabel 3 dan rumus (3) akan terlihat seberapa besar kalor yang terserap pada air pendingin. Persentasenya dicari dengan membandingkan kalor yang diserap air pendingin dengan kalor yang diberikan mesin kepada cetakan. Tabel 5 memperlihatkan perbandingan kalor yang diserap air pendingin, dan persentase kalor yang diserap sesuai dengan parameternya masing-masing

Dari Tabel 5 diperlihatkan dengan jelas bahwa temperatur pemanasan $110^{\circ} \mathrm{C}$ membuat persentase kalor yang terserap pada air pendingin menjadi sangat kecil dibandingkan dengan sampel dengan pemanasan $120^{\circ} \mathrm{C}$ atau $130^{\circ} \mathrm{C}$. Hal ini disebabkan karena pada temperatur $110^{\circ} \mathrm{C}$, PVC cenderung menyerap panas ketimbang melepasnya kepada molding aluminium 
yang didinginkan oleh air pendingin, itulah sebabnya panas yang terserap oleh air pendingin menjadi hanya kisara $17-30 \%$. Walau demikian tabel 5 juga memperlihatkan persentase kalor yang diserap oleh air pendingin bertambah seiring temperatur pendinginan dinaikkan. Hal ini disebabkan karena kalor yang diserap oleh cetakan menjadi lebih kecil, sehingga jumlah kalor yang terserap pada air pendingin dengan temperatur pemanasan $110^{\circ} \mathrm{C}$ nampak seperti membesar, padahal jumlahnya sama.

Tabel 5. Jumlah kalor yang diserap air pendingin berdasarkan parameter sampel

\begin{tabular}{ccccc}
\hline $\begin{array}{c}\text { Spesimen } \\
\text { uji }\end{array}$ & $\begin{array}{c}\text { Setting } \\
\text { Temperatur } \\
\text { Forming }\left({ }^{\circ} \mathrm{C}\right)\end{array}$ & $\begin{array}{c}\text { Temperatur air } \\
\text { setelah cetakan } \\
\left({ }^{\circ} \mathrm{C}\right)\end{array}$ & $\begin{array}{c}\text { Kalor yang } \\
\text { diserap } \\
\text { pendingin }\end{array}$ & $\begin{array}{c}\text { Persentase } \\
\text { Kalor terserap } \\
(\%)\end{array}$ \\
\hline A.1 & & 19,3 & 189 & 17.01 \\
A.2 & 19 & 19,8 & 504 & 40.87 \\
A.3 & & 20,1 & 693.01 & 51.1 \\
B.1 & & 21,6 & 378 & 34.8 \\
B.2 & 21 & 22,1 & 693.01 & 57.36 \\
B.3 & & 22,7 & 1071.01 & 80.34 \\
C.1 & & 25,9 & 567 & 54.67 \\
C.2 & 25 & 26,4 & 882.01 & 76.1 \\
C.3 & & 27,1 & 1323 & 100 \\
\hline
\end{tabular}

3.2. Visual dan Toleransi

Tabel 6. Cek visual untuk setiap parameter

\begin{tabular}{cc}
\hline Spesimen uji & Hasil visual \\
\hline A.1 & Pocket tidak terbentuk \\
A.2 & Pocket bagus \\
A.3 & Pocket bagus \\
B.1 & Pocket tidak terbentuk \\
B.2 & Pocket bagus \\
B.3 & Pocket bagus \\
C. 1 & Pocket tidak terbentuk \\
C. 2 & Pocket tipis \\
C. 3 & Pocket bolong \\
\hline
\end{tabular}

Pengecekan visual dilakukan untuk memvalidasi perbandingan kualitas cetakan dengan penyerapan pendinginan yang sudah disebutkan sebelumnya. Dapat diperlihatkan bahwa semua poket/blister yang dipanaskan pada temperatur $110^{\circ} \mathrm{C}$ dengan forming temperature berapapun menghasilkan poket yang tidak terbentuk (failure).

Hal ini disebabkan temperatur pemanasan PVC yang dipilih terlalu rendah, sehingga mengakibatkan PVC tidak pada kondisi dapat ditekan (elastis). PVC mempunyai temperatur kerja maksimum pada $110^{\circ} \mathrm{C}$, ditambah lagi proses pendinginan yang diberikan pada cetakan mengakibatkan PVC sudah terlebih dahulu dingin sebelum dibentuk sesuai dengan cetakannya. Gambar 6 a menunjukkan kualitas blister yang tidak berbentuk pada temperatur pemanasan $110^{\circ} \mathrm{C}$.

Gambar 6 b dan c menampilkan hasil dari cetakan blister yang dibuat pada temperatur pemanasan $120^{\circ} \mathrm{C}$ dan $130^{\circ} \mathrm{C}$. kedua temperatur pemanasan ini menghasilkan kualitas yang baik secara visual. 

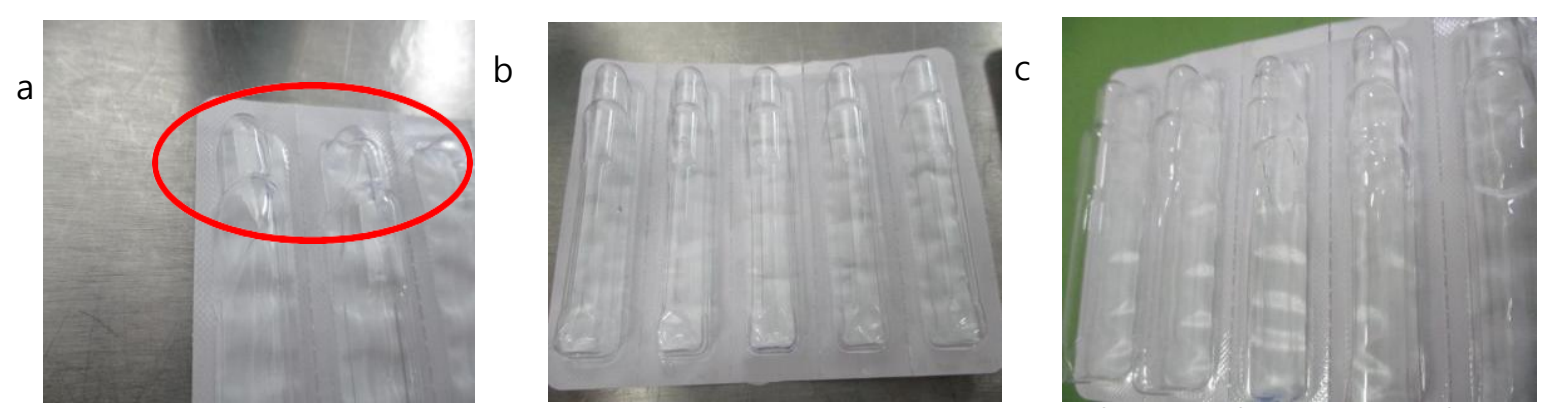

Gambar 6. Pemeriksaan visual untuk temperatur pemanasan a) $\left.110^{\circ} \mathrm{C} \mathrm{b}\right) 120^{\circ} \mathrm{C}$ dan c) $130^{\circ} \mathrm{C}$

Tabel pengukuran dengan menggunakan jangka sorong digital diperlihatkan pada Tabel 7. Masing-masing panjang, tinggi dan lebar diperlihatkan pada Gambar 3.

Tabel 7. Pengukuran sampel blister dengan jangka sorong dan perbandingannya dengan standar

\begin{tabular}{|c|c|c|c|c|c|c|}
\hline \multirow{2}{*}{$\begin{array}{c}\text { Spesimen } \\
\text { uji }\end{array}$} & \multicolumn{3}{|c|}{ Standart pengukuran $(\mathrm{mm})$} & \multicolumn{3}{|c|}{ Hasil Pengukuran (mm) } \\
\hline & Panjang & Tinggi & Lebar & Panjang & Tinggi & Lebar \\
\hline A.1 & & & & 64,70 & 12,14 & 12,11 \\
\hline A. 2 & & & & 64,99 & 12,48 & 12,19 \\
\hline A. 3 & & & & 64,98 & 12,46 & 12,18 \\
\hline B. 1 & & & & 64,74 & 12,21 & 12,11 \\
\hline B. 2 & 65 & 12,5 & 12,2 & 64,82 & 12,43 & 12,18 \\
\hline B. 3 & & & & 64,98 & 12,47 & 12,18 \\
\hline C.1 & & & & 64,88 & 12,43 & 12,14 \\
\hline C. 2 & & & & 64,90 & 12,49 & 12,17 \\
\hline C. 3 & & & & 64,95 & 12,49 & 12,19 \\
\hline
\end{tabular}

Pengukuran menunjukkan bahwa dimensi terjauh dialami oleh sampel blister yang dipanaskan dengan temperatur $110^{\circ} \mathrm{C}$. Namun, jika dilihat dari penjelasan-penjelasan sebelumnya, baik tentang kalor yang diserap sistem pendingin, serta pemilihan temperatur pemanasan yang terlalu rendah, maka dapat disimpulkan bahwa cacat yang ditemui di sini bukan merupakan jenis shrinkage atau penyusutan dimensi, namun lebih kepada pembentukan yang tidak sempurna.

Gambar 8 menunjukkan dengan lebih jelas sejauh mana dimensi aktual hasil pengukuran menyimpang dari standar yang diharapkan untuk dimensi blister tersebut. Dimensi yang diharapkan untuk panjang, lebar dan tinggi dari blister ditandai dengan garis putus-puts warna merah.

Jika gambar 8 ini dibandingkan dengan Tabel 5, maka dapat disimpulkan bahwa penyerapan kalor diatas $40 \%$ menghasilkan dimensi yang tidak terlalu jauh dari standar yang diharapkan, khusus bagi sampel blister yang dipanaskan pada temperatur $120^{\circ} \mathrm{C}$ dan $130^{\circ} \mathrm{C}$. 


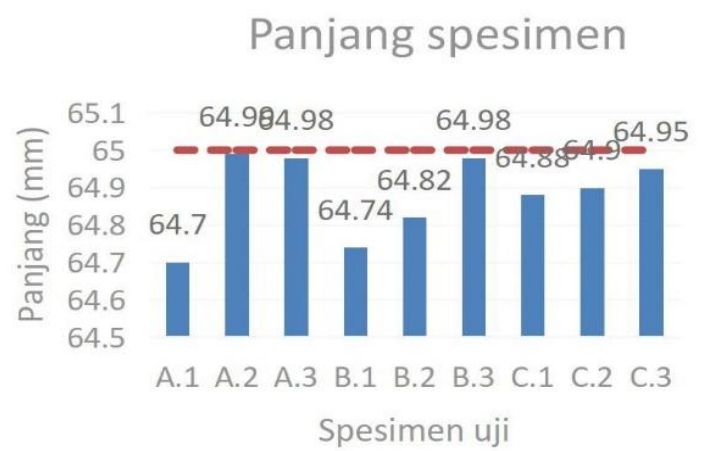

Panjang spesimen - - - Standa
Tinggi spesimen

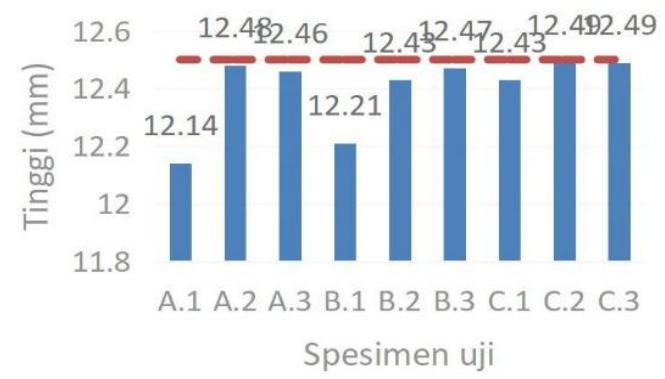

Tinggi spesimen - - - Standart

\section{Lebar spesimen}

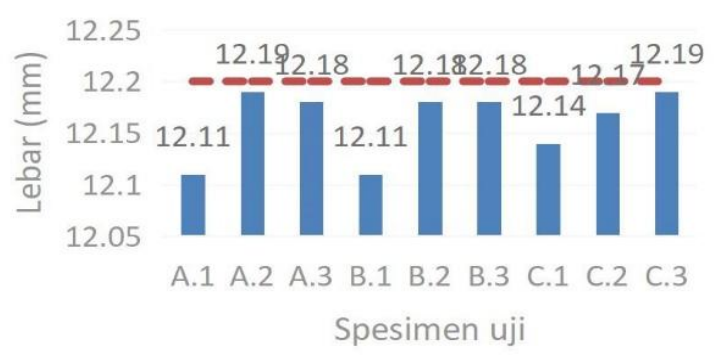

Lebar spesimen - - - Standart

Gambar 8. Perbandingan hasil pengukuran sampel dengan jangka sorong dalam bentuk histogram

\subsection{Kebocoran}

Tabel 8. Pengecekan kebocoran dengan menggunakan pompa vakum pada tiap sampel

\begin{tabular}{cccc} 
Spesimen uji & Vakum & $\begin{array}{c}\text { Holding } \\
\text { time }\end{array}$ & $\begin{array}{c}\text { Hasil } \\
\text { Kebocoran }\end{array}$ \\
\hline A.1 & & & Tidak bocor \\
A.2 & & & Tidak bocor \\
A.3 & & & Tidak bocor \\
B.1 & & Tidak bocor \\
B. 2 & $20 \mathrm{cmHg}$ & 1 menit & Tidak bocor \\
B.3 & & & Tidak bocor \\
C.1 & & & Tidak bocor \\
C. 2 & & & Tidak bocor \\
C. 3 & & & Bocor \\
\hline
\end{tabular}

Tabel diatas memperlihatkan kondisi kebocoran yang dicek untuk setiap parameter blister. Pada tabel ini diperlihatkan bahwa sampel C3 (dipanaskan pada temperatur $130^{\circ} \mathrm{C}$ dan dibentuk pada temperatur $25^{\circ} \mathrm{C}$ ) mengalami kebocoran yang lebih berbentuk bolong-bolong walau pada sisi visual dan toleransi sampel ini menunjukkan kondisi yang baik.

Pada Tabel 5 diperlihatkan bahwa penyerapan kalor pada cetakan ini hingga mencapai $100 \%$ yang menyatakan bahwa sebenarnya PVC sedang pada tahap terlalu panas sehingga mengakibatkan pori-pori pada lapisan tipis dari blister. Kondisi pori ini yang mengakibatkan kebocoran saat pengecekan. 


\section{SIMPULAN}

Penambahan temperatur forming temperature akan mengakibatkan pelepasan kalor yang semakin kurang, sementara penambahan temperatur pemanasan akan mengakibatkan kalor yang dilepas oleh mesin semakin tinggi.

Percobaan diatas menunjukkan kesimpulan sebagai berikut bahwa pemilihan temperatur pemanasan yang terlalu rendah akan mengakibatkan pembentukan material yang tidak sempurna pada cetakan.

Percobaan pengukuran toleransi juga menunjukkan bahwa pendinginan yang baik (tidak terlalu cepat dan tidak terlalu lambat) akan menyebabkan penyusutan dimensi (shrinkage) yang tidak terlalu jauh. Namun pendinginan yang terlalu tinggi akan menyebabkan pori yang terjadi pada PVC dan mengakibatkan kebocoran.

\section{UCAPAN TERIMA KASIH}

Ucapan terima kasih disampaikan kepada

- Universitas Kristen Indonesia yang memfasilitasi penulisan dan penyediaan paper-paper yang disediakan.

- Universitas Udayana yang sudah menyediakan tempat untuk mempublikasikan penelitian saya

- Kepada Benedictus sebagai pribadi yang telah mengambil data yang cukup

- Kepada pihak-pihak yang telah membantu baik secara langsung maupun tidak langsung.

\section{DAFTAR PUSTAKA}

[1] J. L. Throne, Thermoforming, Encyclopedia of Polymer Science and Technology, American Cancer Society, 2003.

[2] J. K. Lee, C. E. Scott, and T. L. Virkler, Effects of rheological properties and processing parameters on ABS thermoforming, Polym. Eng. Sci., vol. 41, no. 2, pp. 240-261, 2001.

[3] A. D. Anggono, Prediksi Shrinkage Untuk Menghindari Cacat Produk Pada Plastic Injection, 2005.

[4] A. I. Ramadhan, E. Diniardi, and M. Daroji, Analisa Penyusutan Produk Plastik di Proses Injection Molding Menggunakan Media Pendingin Cooling Tower dan Udara dengan Material Polypropylene, JRST J. Ris. Sains Dan Teknol., vol. 1, no. 2, pp. 6574, 2017.

[5] E. Sunarto and I. E. P. M. KKK, "Pengaruh Proses Pendinginan Terhadap shrinkage dan Dimensi Produk Ts Plug 1" Berbahan PVC pada Injecion Molding, Pros. SENIATI, pp. 235-241, 2018.

[6] D. HERMANSYAH, Pengaruh Sistem Pendinginan Lurus, Conformal Laminasi dan Conformal soft Tooling Terhadap Penyusutan Dimensi Produk Pada Mesin Injeksi Plastik, PhD Thesis, Universitas Muhammadiyah Surakarta, 2011.

[7] A. Afendi, Pengaruh Diameter Saluran Pendingin Ukuran \$1/2\$” Dan \$1/4\$” Pada Cetakan Soft Tooling Serbuk Alumunium Terhadap Penyusutan Pada Mesin Injeksi Plastik, PhD Thesis, Universitas Muhammadiyah Surakarta, 2011.

[8] F. APRIYANTO, Pengaruh Diameter Saluran Sistem Pendingian Ukuran 6, $35 \mathrm{~mm}$ dan 11, 5 mm Pada Cetakan Conformal Soft Tooling Bahan Kuningan Terhadap Penyusutan Dimensi Produk Pada Mesin Injeksi Plastik, PhD Thesis, Universitas Muhammadiyah Surakarta, 2011.

[9] W. A. W. Ula, Analisis Perpindahan Panas Pada Pipa Kalor Bertingkat, J. Mettek J. Ilm. Nas. Dalam Bid. Ilmu Tek. Mesin, vol. 5, no. 2, pp. 74-78, 2019.

[10] J. Darmawan and B. W. Febriantoko, Pengaruh Variasi Suhu Terhadap Cacat Short Shot Pada Produk Injection Molding Berbahan Polypropylene (PP), PhD Thesis, Universitas Muhammadiyah Surakarta, 2018. 
[11] D. KURNIAWAN, Pengaruh Suhu dan Waktu terhadap Hasil Cetak Plastik dengan Mold dari Aluminium Pada Proses Mechanical Thermoforming, PhD Thesis, Universitas Muhammadiyah Surakarta, 2011.

[12] A. Nuari, Analisis Laju Aliran Panas pada Proses Thermoforming Blister Packing Mesin Pam-pac Bp-102 dengan 2 Desain, J. Tek. Mesin Mercu Buana, vol. 6, no. 3, pp. 207214, 2017.

[13] "Fig.5. Specific heat capacity curve of PVC with rising temperature [11].," ResearchGate. https://www.researchgate.net/figure/Specific-heat-capacity-curve-ofPVC-with-rising-temperature-11_fig5_242724319 (accessed Mar. 12, 2020). 